\title{
A STRATEGIC ANALYSIS FOR PATANJALI AYURVED LTD. ALSO IN SWADESHI FRAMEWORK
}

\author{
Srishti Jain \\ MBA Marketing and sales \\ Amity Business School, \\ Amity University, \\ Noida
}

Article DOI: https://doi.org/10.36713/epra5127

\begin{abstract}
This firm was created through Swami Guru-Baba Ramdev, partnering with Acharya Balkrishna, a scholar of Ayurveda, Sanskrit, and Vedas in the 1990's to produce herbal products. Ramdev concentrated on Relaxation while Balkrishna took care of helping to spread herbal products. The Consumer goods collection for beauty and Relaxation for Self satisfaction have done a wonderful job in Swadesh which is really the company's biggest target. Swami Ramdev was impactful in both. His live broadcast of regular exercise on Aastha Network has gained him a broad audience, and its FMCG business is assisting nation in its product of India drive. Each objective of the organization is to get more Herbal / Ayurvedic / natural and organic ingredients to all the challenges. This article attempts to examine the scenario of Patanjali Ayurved Ltd \& its own contributions to society to the people via its business activities \& the effort mostly to betterment of the public.
\end{abstract}

KEYWORDS: Relaxation, herbal product, Consumer goods, betterment, Swadesh, Patanjali

\section{INTRODUCTION}

Patanjali Ayurved india's largest Consumer durables company based in the Haridwar industrial district. The intention of developing the herbal method in segment with others and collaborating with both the newest technology and traditional beliefs. Patanjali Helps starting with the manufacture of herbal medicines items. They have steadily extended their variety from either the manufacture of medications to the manufacture of foodstuffs and cosmetic products. They also steadily widened their reach including assembling the Herbs used to produce foodstuffs and personal care products. Swami Ramdev has chosen Swadeshi's direction, which represents Product of India, Swadeshi becomes generally an initiative of India and therefore by producing Patanjali Ayurved . The business offered shoppers a Herbal easy solution and, but at the other hand, it hold different and Unique identity comparing to others FMCG company. Currently Patanjali appeared as among the most popular brands in India in today's context. Each Indian recognizes Patanjali even though a few of their commodities in certain manner or another have certainly affected their lives. And if they're not used, less would or might have missed out on proper advertisements which actually took over every Indian network. Company serves all Indians through its Commodities or via the "Swadeshi" approach to improve the economic growth.

\section{LITERATURE REVIEW}

Few studies found that different variety has deep roots and the nation's traditions make it tough for a marketing company to settle for a consistent business model. It was observed however after a huge attention to Mass people, people in different societies have different opinions, expectations, interests, desires and principles. According to the business unit and its organization the goods are produced through the study of attractiveness and brand image. Majority Researchers talk about the great knowledge of productive life within buyers that focuses wellness services from Ayurvedic and meditation. It therefore gives strength to the Patanjali products, as they are both Ayurvedic, herbal commodities and Baba Ramdev as yoga Genius who upholds healthy and nutritious values. 


\section{SCOPE OF THE STUDY}

This study has been conducted mostly on progress in reasonable costs of Swadeshi commodities in India on the basis of growing Indian Economy and improving human well-being. The vast majority of the people consider purchasing after taking an interest in the brand's accessibility. This really is cost effective but differentiated items for Ayurveda that are directed at Connect with citizens. Because then they belong to the targeted audience.

\section{OBJECTIVES OF THE STUDY}

1. To understand how "Patanjali Helped" Swadeshi commodities Ltd "will establish the Product of India Campaign effectively.

2. Analyzing the firm's USP.

3. Study the "Patanjali Ayurved Ltd" SWOT

\section{RESEARCH METHODOLOGY}

This analysis of secondary data obtained from newspaper, journal, and other reliable data are being used to gather knowledge about the brands 'Patanjali.' Writings, papers, case studies etc. have been conducted in order to gain information into the past initiatives that are now in place by the participants and decision makers.

\section{FINDINGS}

- The company implements Purpose related products, whatever the company gets they raise for the betterment of people and enhances people's health, i.e. it benefits farmers, so the company has set goals for producing such outputs and ensuring their goods.

- It plays a very important role in raising the country's GDP.

- The firm's unique sales strategy that is safe and natural quality in terms of the goods.

The SWOT analyses of company

- $\quad$ Strengths

i. The brand recognition is the whole framework for their loyalty

ii. The ultimate transmission of Patanjali advertisements

iii. The assurance of goods and their catch phrase is "Sasta Bhi, Acha Bhi

iv. The business expanded rapidly in just a brief time period.

- Weakness

i. No access of product at rural areas

ii. Limited availability at distributors
- Opportunity

i. Can also be used in clothing diversification

ii. Increasing Organic Business

- Threats

i. Negative image on Social Media

\section{CONCLUSION}

This decision relates to patanjali and Swami leading to the conclusion that Ramdev is becoming a label by far the most impact on the Indian market relevant strategy to create itself as a mark first appearance and then place the line of products on patanjali on right reason to get the right Swadeshi Alternative potential customers.

\section{BIBLIOGRAPHY}

1. Bureau, B. O. (2020, june). COVID-19 Cure Possible Through Ayurveda, Patanjali Case Study Showed $100 \%$ Favorable Results, Claims Acharya Balkrishna. Retrieved from businessworld.in: http://www.businessworld.in/article/COVID-19Cure-Possible-Through-Ayurveda-Patanjali-CaseStudy-Showed-100-Favorable-Results-ClaimsAcharya-Balkrishna/14-06-2020-287122/

2. Gopal, B. S. (2016). Demystifying the Brand Patanjali - A Case on Growth Strategies of Patanjali Ayurved Ltd. ResearchGate .

3. Mehrotra, S. (2017, june). Patanjali: an Indian FMCG on growth path. Retrieved from emeraldinsight:

https://www.emerald.com/insight/content/doi/10.11 08/EEMCS-07-2016-0159/full/html

4. Patanjali Case study(Business Model) How Ramdev Made est. ₹10,216 cr. (2020, March). Retrieved from lapaas.com: https://lapaas.com/patanjali-case-studybusinessmodel-how-ramdev-made-est-\%E2\%82\%B910216$\mathrm{cr} /$

5. Prasad, N. (2018). The Rise of Patanjali. SAGE Journals .

6. What Made Patanjali The Indian FMCG King? (n.d.). Retrieved from walnutfolks: https://walnutfolks.com/patanjali-case-study/ 